\title{
New managerialism, neoliberalism and ranking
}

\author{
Kathleen Lynch \\ Equality Studies Centre, School of Social Justice, University College Dublin, Belfield, Dublin 4, Ireland
}

\begin{abstract}
This paper analyses the ranking of universities within the socio-political context of neoliberalism and the organisational context of new managerialism. It examines the forces that have facilitated the emergence of the ranking industry and the ideologies underpinning the so-called 'global' university rankings. What the paper shows is that rankings are a politically inspired mode of governance; they are designed to ensure that universities are regulated and controlled in accordance with market values. The seemingly objective character of rankings, in particular the use of numbers, creates an impression that what is of value in education can be simply counted, hierarchically ordered and uncontrovertibly judged. The simplicity and accessibility of rankings deflects attention from their political and moral purposes. Rankings are reconstituting the academy, for both academics and students; they are a new mode of external governance through which market values are reframing the social relations of education. They have altered the cognitive and moral frames through which university education is being appraised. The paper calls for a debate on the public interest objectives of universities in the context of growing market regulation.
\end{abstract}

KEY WORDS: New managerialism · Neoliberalism · Public Interests · Markets · Ideological tool · Culture $\cdot$ Measurement

\section{UNIVERSITIES AND PUBLIC INTERESTS}

The history of Universities shows that they have varied in their purposes historically ${ }^{1}$, although they have always been 'communities of scholars' who worked to defend their academic freedom (Hamlyn 1996). Independence of intellectual thought is thus a defining attribute of Universities, enabling scholars to pursue research and teaching outside the control of powerful interest groups (Newman

\footnotetext{
${ }^{1}$ Universities changed from being centres for the study of theology, law and medicine in the Middle Ages to incorporating the arts, philosophy and sciences in the Renaissance period. They slowly opened to new disciplines like sociology and economics in the 19th century. The formal linking of scholarship and teaching was particularly developed in Germany at the University of Berlin in 1910, under Von Humboldt and his colleagues, and with the support of the Prussian government (Hamlyn 1996, p. 205-206).
}

$1852)^{2}$. That is why Newman, in his enunciation of 'The Idea of a University', was adamant that the university 'contemplates neither moral impression nor mechanical production' (Newman 1852,

\footnotetext{
2The purpose of the university is: 'To open the mind, to correct it, to refine it, to enable it to know, and to digest, master, rule, and use its knowledge, to give it power over its own faculties, application, flexibility, method, critical exactness, sagacity, resource, address, eloquent expression, is an object as intelligible (for here we are inquiring, not what the object of a Liberal Education is worth, nor what use the Church makes of it, but what it is in itself' (Newman 1852, p. 122-123). He goes on to say '.... a University, taken in its bare idea, ....has this object and this mission; it contemplates neither moral impression nor mechanical production; it professes to exercise the mind neither in art nor in duty; its function is intellectual culture; ...It educates the intellect to reason well in all matters, to reach out towards truth, and to grasp it.' Newman 1852/58: Discourse 6. Knowledge Viewed in Relation to Learning, p. 125-126). Available at www.newmanreader.org/works/ idea/discourse6.html (accessed August 6, 2013).
} 
p. 125-6). It is expected to be a watchdog for the free interchange of ideas in society and is licensed accordingly to protect freedom of thought, including the freedom to dissent from prevailing orthodoxies. The University is presumed to serve the public good and to equate its own self-interest, in research and education terms, with the public interest (Lieberwitz 2005). While the public know that knowledge and research conducted by profitdriven operations and/or by other powerful interests within the State can be and are often subject to political influence, it is assumed that this is not the norm in the university. The status and credibility of scholarship in universities therefore stems to a considerable extent from its disinterestedness and detachment from the powerful (De La Fuente 2002, Lieberwitz 2005). Consequently, university teaching and research has been largely funded from the public purse in Europe (ECOFIN 2010). Even in pro-market countries such as the USA, between 70 and $80 \%$ of university life sciences research is publicly funded (Lieberwitz 2005).

\section{MAKING MARKETS IN HIGHER EDUCATION}

Over the last $20 \mathrm{yr}$, there has been a global movement to radically alter the role of the university (Robertson et al. 2002, Angus 2004, Bullen et al. 2004) and in particular to reduce the amount of public investment in higher education generally. There is a growing expectation that universities should be selffinancing through external collaborations with business in particular (Europa 2011, p. 1) ${ }^{3}$. In the United Kingdom (UK), private higher education providers are regarded by government as a mechanism for reducing the cost of higher education to the exchequer (Ball 2012, p. 21), and university education is increasingly defined as a market commodity (Slaughter \& Leslie 1997). Universities have been transformed into powerful consumer-oriented corporate networks, where public-interest values are seriously challenged (Rutherford 2005, Ball 2012). The factors that have contributed to corporatisation and commercialisation are notable, not only in and of themselves, but also

3 OJC 372/36, the Official Journal of the European Union, 20.12.2011, p. 1, reported that there was a need to reform further the governance and financing structures of universities allowing for greater autonomy and accountability, so as to facilitate a more diversified revenue stream and more effective collaboration with the business world and to equip universities to participate in the knowledge triangle on a global scale. because of how they have reframed the orientation and purposes of higher education.

Multilateral agencies including the Organisation for Economic Co-operation and Development (OECD) and the World Bank, and political institutions such as the European Union (EU), exercise increasing influence over national education policies. Control and regulation is often indirect, as in the form of 'advice' from the World Bank or the OECD: the 'Country Reports' of the OECD are thinly disguised 'surveillance' procedures promulgating a new market instrumentalism in education under the guise of 'independent' expertise (Henry et al. 2001). While control may be exercised as 'soft' power in higher education, it is real power nonetheless (Lo 2011).

The World Bank was one of the first major bodies to promote higher education as a marketable commodity ${ }^{4}$. It heralded this development in the early 1990s in Higher Education: The Lessons of Experience (World Bank 1994). The 1994 report promoted the idea of developing private universities, making public funding for universities subject to performance, and encouraging greater reliance on private funding for higher education. While many working in Western and Northern universities took little notice of either the 1994 report or the 1998/99 World Development Report: Knowledge for Development, assuming these to apply to African and other poorer countries, they were a portent of what was to apply to all universities (World Bank 1998). Follow-up World Bank reports, Constructing Knowledge Societies (World Bank 2002) and The Challenge of Establishing World Class Universities (World Bank 2009), have consolidated the market-led view of universities globally. New mechanisms of control and regulation of Universities' productivity were developed, not only within, but between countries (Hazelkorn 2011); rankings became an integral part of a new mode of market governance (Marginson 2007a).

One other very important factor contributing to the marketisation of higher education lies deep within the dynamics of globalisation and the changing relationship between the services, manufacturing and agricultural sectors of the economy. The investment returns from manufacturing have declined signifi-

\footnotetext{
${ }^{4}$ The World Bank is the largest multilateral source of funding for education in the world and as such plays a key role in framing education policies globally. 'However, the World Bank is not bound by international law nor does it acknowledge that education is a human right' (Tomasevski 2005, p. 6). The reason for this anomalous situation is explained in Tomasevski $(2005$, footnote 15, p. 6).
} 
cantly in rich capitalist economies in recent decades, for a range of complex reasons, not least of which is the emergence of a large, non-unionised labour pool for manufacturing in South East Asia. Agriculture, already a relatively minor player in employment terms in Western and Northern economics, could not provide alternative forms of employment to manufacturing. The focus shifted to trade in services, including trade in some or all of particular public services. The pressure to move education from a public service to a tradable service was also very much part of the ideology of the General Agreement on Trade and Services (GATS) agreement, the purpose of which is to liberalise all services in all sectors of the economy globally (Roberston et al. 2002, Tomasevski 2005). The rationale for making education a tradable service was articulated by Merrill Lynch ${ }^{\underline{5}}$ in The Book of Knowledge in 1999. It defined education as a service that presents major new opportunities for investors in profit terms (Moeet al. 1999). In 2000, UNESCO estimated that education was a $\$ 2$ trillion global 'industry', so there was potential for profitable returns if such a service could be traded, especially among those sectors of society that could afford to pay for it.

Globalisation (which involves interaction across national borders unmediated by the state) also had far-reaching direct effects on higher education. When aligned with the deregulation of trade in services under the GATS, globalisation enabled the convergence and integration of markets, including markets in higher education. Global technologies facilitated instant communication and the transportation of ideas, money and students across national borders with increasing ease (Hazelkorn 2011). Distances of time and space were compressed and deregulation facilitated trading in knowledge and university degrees as commodities. Part of the trade involved trading images and rankings of individual universities. What was national and private, was made public and global.

The rise of influential and financially endowed social movements in the USA to promote for-profit higher education in particular (Covington 2001), and the fact that there are now several hundred for-profit colleges and Universities across the world, are indications that for-profit trading in higher education is also well established (Hill 2005). Private higher education is worth an estimated $\$ 400$ billion globally and about one quarter of all higher education students

${ }^{5}$ Merrill Lynch is a USA-based Global Financial Management company with offices in 36 countries. are in private colleges (Ball 2012, p. 20). The services sector, including the sale of education, has gradually begun to make up the employment deficit of manufacturing (D'Agostino et al. 2006), and both the EU and the USA have seen a rise in a range of tradable services in recent decades ${ }^{\mathbf{6}}$.

As the State was and is a major player in the economy, it also began to explore what services it could sell. Services that were defined as rights under one code of ethics (notably health and education) mutated to being marketable commodities under another (Tomasveki 2005). Higher education was increasingly defined as a private rather than a public good (Chubb \& Moe 1990, Tooley 2000), and as such was tradable.

At an ideological level, a not insignificant factor precipitating the marketisation of higher education was the ascendancy of neoliberal capitalism from the later 1980s. The hegemony of liberal democracy and free market capitalism that ensued from the demise of communism brought with it widespread allegiance to the liberalisation of trade and services (Fukuyama 1992). Neoliberalism, which had been nascent but not global under the influence of Hayek and Friedman, was given a new lease of life, a life that was deliberatively planned and orchestrated at a political level from the 1970s onwards, especially in the USA (Harvey 2005, p. 39-63). With its explicit anti-redistributive goals and its legitimation of nonredistribution through the powerful ideologies of possessive individualism and choice, neoliberalism paved the way for reducing public expenditures on education, including higher education. The rise of the 'small state' ideology led to a declining commitment to invest in public services, including higher education, at a time of expansion. The discourse around education changed from one focused on rights and needs to one focused on markets and choices. This had adverse effects on poorer people, as paying even for compulsory education became normalised in many states in Asia, South America and Africa (Tomasevski 2005). As cash-strapped governments recognised the potential of higher education to become a net contributor rather than cost to the exchequer, the marketisation for higher education through trading on identities, brands and rankings was inevitable.

\footnotetext{
${ }^{6}$ These included community, social and personal services, retail and wholesale services, including hotels, restaurants, transport and communication services, financial services, including insurance and real estate much of which was highly speculative and unproductive in real service terms.
} 
The response to the marketising of higher education has been immediate and dramatic. Australia increased its overall share of the world's population of cross-border students from 1 to $9 \%$ between 1990 and 2003 (Marginson 2007b, p. 8). Education is now one of its biggest exports, estimated to be valued at Aus\$17.2 billion in 2008 to 2009, or about $1.4 \%$ of GDP (OECD 2013). In the UK, the export of education services by universities amounted to $£ 23.4$ billion (US\$43 billion) in 2007 to 2008. In gross output terms, this was equal to the output of the 'printing and publishing industry, and considerably larger than the pharmaceuticals industry' (Marginson 2007b, p. 8). 'If higher education were an industry, it would be one of the world's biggest and most dynamic' (OECD 2013).

Fed by rankings and marketing, student flows are increasing around the world. The numbers of students who are studying outside their own countries has increased by 2.7 million or $50 \%$ since 2000. 'If current trends continue by 2025, almost 8 million students will be studying outside their home countries' (Ball 2012, p. 20). The economies of English-speaking countries (and English-based programmes within countries) remain the principal beneficiaries of the new higher education trade. In the mid-2000s, 46\% of the students who crossed borders to study moved from China, India and other Asian countries to OECD countries, mostly to English-language based education systems (Marginson 2007b, p. 9). Rankings played a major role in determining the new patters of trade, a business that many regard as a form of recolonisation in cultural terms (Deem et al. 2008).

\section{UNIVERSITY DYNAMICS AND MARKETISATION}

The regulation of universities through rankings was also enabled by the internal dynamics of universities themselves. Although universities are public interest bodies, they have not always honoured their public interest commitments (Harkavy 2005). Years of research evidence on the patterns of class inequality in education have shown that not only has higher education done little to challenge class inequality in education over many decades (Shavit \& Blossfeld 1993, Clancy 1995, 2001, Gamoran 2001, Archer et al. 2002, Rumberger 2010, Sianou-Kyrgiou 2010), but there is also little hope of social mobility through education henceforth, even in prosperous countries like the USA (Gamoran 2001, Marsh 2011). Moreover, universities have often been party to the perpetuation of social inequalities. While they played a key role in forming the professional classes of the
post-World War II welfare states (Hanlon 2000), they did not challenge the exclusionary practices of professional associations in the educational field. Rather, they worked with the professional elite to maintain their social class standing. A series of national studies of entrants to higher education in Ireland spanning almost 20 yr shows that students entering the professional faculties of law, medicine, dentistry, architecture and veterinary science have been drawn disproportionately from the middle and upper middle classes (Clancy 1995, 2001). Elite universities of the UK and USA show a similar pattern of exclusivity (Reay et al. 2010, p. 2) ${ }^{\underline{7}}$. The universities' relative indifference to wider societal injustices in terms of access to higher education has meant that they had limited moral standing, and even less public sympathy, when their budgets were cut and they were regulated through ranking.

In their internal operations too, the history of universities shows that they have been hierarchical, patriarchal and, at times, nepotistic (Wenneras \& Wold 1997, Knights \& Richards 2003, Morley 2003, O'Connor 2012). They have not been models of enlightened organisational practice. While there have been critical voices in higher education, critical of its pedagogy and its exclusivity (most notably influenced by the work of the renowned Brazilian philosopher Paulo Freire 1970), dissenters have also been minority voices, often working against the tide even in pre-neoliberal days (Lynch 1995). The claim of the academy that its public-interest functions are being undermined by the neoliberal agenda can ring hollow to those who have lived for generations without the privilege of higher education, and who, with justification, regard universities as sites for the reproduction of the elite, nationally and globally.

\section{NEW MANAGERIALISM}

Neoliberalism is premised on the assumption that the citizen's relationship to the State and others is mediated via the market. New managerialism is the mode of governance aligned with neoliberalism:

\footnotetext{
${ }^{7}$ A study by the Sutton Trust (2007) of the top 13 universities in the UK as measured by press rankings found that, of the 300000 of the nation's university applicants from less affluent social backgrounds, just over $1 \%$ get into one of the top 13 universities. There are similar concerns in the USA where, in the year 2000, students from families in the bottom $50 \%$ of the income distribution made up $10 \%$ of first years at Princeton and $12 \%$ at Harvard, 2 of the US elite universities (Karabel 2005).
} 
it involves governing through enacting technical changes imbued with market values.

New managerialism is not a neutral management strategy, however. Its expressed purpose is to institutionalise market principles in the governance of all organisations (Clarke et al. 2000, p. 7). It involves the inculcation of market values and practices into the regulation and organisation of public services in particular (Farrell \& Morris 2003). Consequently, when and where it is implemented in the public sector, new managerialism focuses service providers on outputs measured in terms of performance indicators and rankings (often regardless of inputs or resources); it emphasises the language of choice, competition and service users; it promotes the decentralisation of budgetary and personal authority to line managers, and project-led contractual employment arrangements rather than permanency (Clarke \& Newman 1997, Clarke et al. 2000 p. 6, Docking 2000, Chandler et al. 2002, Court 2004, Hill 2005). And it endorses strong market-type accountability in public sector spending. The net effect is that meeting financial and other targets is a priority, and success in meeting targets is measured through public audits. The development of quasi-markets for services is also a key goal and rankings feed directly into this process; markets operate as a further form of control through competition and public surveillance of public sector services (Clarke et al. 2000).

What is important about new managerialism is that it was not only exported between countries as a mode of governance (Harvey 2005) but also within countries from the private to the public sector (Boltanski \& Chiapello 2005, Lynch et al. 2012).

\section{NEW MANAGERIALISM AND RANKING}

Rankings are an inevitable output of new managerialism as they are integral to audit and surveillance systems of regulation and control. They alter the internal culture of universities in terms of what they measure (Sauder \& Epseland 2009). They put universities on public display, pressurising them to change from being 'a centre of learning' to being 'a business organisation with productivity targets'. They are expected to transfer allegiance 'from the academic to the operational' (Doring 2002, p. 140). Treating change as a purely 'technical matter', means that market values can be encoded in the heart of the university's operations without reflection. New organisational forms are classified as technical shifts, a change in language and style but not in substance.
However, language does not simply name the world, it defines it. New languages signify much more than a change in terminology. When students become 'customers' this changes their relationship to teachers from one of education to one of market service: they mutate silently from people with rights to education, to customers with preferences (Lolich 2011). When universities focus on 'key performance indicators' this directs attention to measured outputs rather than processes and inputs within education, including those of nurturing and caring (Lynch 2010a).

Much of the power of ranking rests in the neutrality of nomenclature within which it is embedded. The positive connotations of 'modernising universities', introducing new 'management systems' and offering 'students choices' fail to signal the new modes of governance and moral regulation such changes entail. They do not foretell how efficiency and effectiveness can gain hegemonic status at the expense of more broadly based moral and social values related to care, autonomy, respect, trust and equality.

But focusing on measurable outputs has the ultimate impact of defining human relationships in the university in transactional terms, as the means to an end - the end being that of high performance and productivity. This reduces first-order social and moral values to second-order principles; trust, integrity, care and solidarity are subordinated to regulation, control and competition. When managerialist practices achieve hegemonic control, they parasitise and weaken those very values on which the university organisation depends. While few would question the value of efficiency, in terms of maximising the use of available resources, the difficulty with managerialism is that it does not just prioritise efficiency, it suppresses other organisational values so that they become incidental. The net effect of the devaluation of moral purposes in and of themselves is that public services, such as education, are no longer defined as capacity-building public goods.

The first order effect of performativity is to re-orient pedagogical and scholarly activities towards those which are likely to have a positive impact on measureable performance outcomes and are a deflection of attention away from aspects of social, emotional and moral development that have no immediate measureable performance value. The second order effect of performativity is in the possibilities it creates to replace commitment with contract. That is to say, to the extent that HE practices - teaching, writing and researchcan be rendered into calculabilities, they can be re-written as contracts of performance that can, at some point, be put out to tender. (Ball 2012, p. 20) 


\section{THE SELECTIVITY AND ARBITRARINESS OF RANKING SYSTEMS}

Comparing universities nationally and internationally in terms of prestige and power is not a new phenomenon. The development of scientific databases, including the Science Citation Index and the Social Science Citation Index, involving bibliometric measures to assess and rank academics and programmes date back to the 1960s (Amsler \& Bolsmann 2012). The USA published a list of the 'best colleges in the country' in the US News \& World Report in 1983 (based originally on the opinions of college presidents but now expanded to other criteria). In these earlier periods, rankings were person- and subjectspecific in the cases of the citation indices, and national in terms of university rankings, being confined to comparisons within nation states. When higher education was defined as a globally traded commodity, and a global market was created for higher educational services, then new modes of ranking were inevitable.

Ranking universities has become big business, not only in marketing universities but also in promoting journals and selling news reports (Lynch et al. 2012, p. 205-224). A wide range of ranking schemes have been devised, not only within countries, but more importantly between them (Salmi 2009, Hazelkorn 2011, Lo 2011, Huang 2012). The power and influence of rankings is reflected in the fact that the European University Association has undertaken a series of studies of rankings and produced 2 major reports on their impact (Rauhvargers 2011, 2013) 을 $^{\mathbf{B}}$ with further reports planned.

Amongst the best known global rankings (all of which use different criteria and rank subjects differently, and all of which are changing regularly) are the ARWU (Academic Ranking of World Universities, sometimes known as the Shanghai Jiao Tong University Ranking), the Times Higher Education World University (THE) rankings, and, since they separated from the THE in 2010, the QS (Quacquarelli Symonds) rankings (within which there are a number of different rankings). Apart from the 3 major ranking systems there are also other rankings, including the CWTS Leiden Ranking system (bibliometric only), the NTU (Taiwan National University Ranking) (ranking of scientific papers) and the German CHE (Centrum für Hochschulentwicklung) based on multiple criteria. China, Spain, Macedonia and a range of other countries also have their own ranking systems (Huang 2012, Rauhvargers 2013)ํ․
Both the THE and QS rankings give a heavy weighting ( $40 \%$ in QS and $34.5 \%$ in THE in $2012^{10}$ ) to what is called reputational ranking based on online surveys to academics ${ }^{11}$. There are a range of problems with such 'surveys', as they are not based on stratified random samples of academics from across the world or across disciplines, and there is an inherent bias towards English-speaking countries in both the THE and QS surveys (Huang 2012, Kaba 2012, Rauhvargers 2013).

The ARWU does not use reputational surveys to assess rank, nor does it include the humanities and most social sciences in ranking universities ${ }^{\mathbf{1 2}}$. Although some ranking schemes do include humanities and social sciences, 'the arts and humanities, and to a large extent the social sciences remain underrepresented in rankings. The relative neglect stems from persistent biases that remain in bibliometric indicators and field-normalised citation counts...In the arts, humanities and the social sciences, published research output is concentrated in books' (Rauhvargers 2013, p. 18-19) and these are not counted effectively in the major databases used to assess citations, namely Thompson Reuters and Elsevier (Rauhvargers 2013). The net effect of this is that universities with strong traditions in the arts, humanities and social sciences cannot feature highly on global rankings.

A further issue is that even those rankings that purport to be 'global' do not rate over $90 \%$ of the world's 15000 universities (Hazelkorn 2011). The most influential global rankings, such as the THE ranking (first published in 2004) and the ARWU (first published in 2003), rate only between 2 and $5 \%$ of the world's universities (Hazelkorn 2011). None of the major socalled global rankings (THE, ARWU or QS) survey the student population regarding their educational experience in a given year; as education is a major object of universities, this is a notable omission $\underline{\underline{13}}$.

There is also the problem of vested interests in rankings. The ARWU is only science-focused, and

${ }^{9}$ Hazelkorn (2011) also has an extensive comparative review.

${ }^{10}$ As the weighting given to different criteria is changing regularly among the ranking agencies (Rauhvargers 2013), these figures only apply to 2012 .

11 QS ranking criteria and weighting: www.iu.qs.com/ university-rankings/rankings-indicators/ (accessed April 28, 2013). Times Higher Ranking: www.timeshighereducation. co.uk/413382.article (Times Higher Education Supplement, September 7, 2010 scheme; accessed April 28, 2013).

12 ARWU-Shanghai Jiao Tong ranking: www.universityran kings.ch/methodology/shanghai_jiao_tong (accessed April 28, 2013). 
relies heavily on Thompson Reuters for its data which is entirely journal-based. The THE also uses data provided by Thompson Reuters. QS uses data from Scopus, which is part of Elsevier. As both Thompson Reuters and Elsevier are major publishers of journals, each has an interest in encouraging the ranking of universities based on journals (Amsler \& Bolsmann 2012 , p. 286). An indirect effect of ranking by the status of journal publications is the undermining of new disciplines and fields of scholarship (especially as these cannot have 'elite' journals in their developmental phase). Thus, the business of university ranking is governed by values and interests other than those of assessing the quality of research and teaching. Given this, the role that the publishing industry plays in determining and advancing university rankings needs to be further investigated.

While universities are global in their relations, those that are publicly funded (which are the majority of universities in Europe) have to serve regional and national objectives. They are not research institutes but universities and as such have an educational remit (Newman 1852). As teaching institutions they have obligations to uphold International Treaties granting people equal access to education, including higher education ${ }^{14}$. Given that most nation states ${ }^{15}$ have ratified the International Convention on Economic and Social and Cultural Rights (ICESCR), and that Article 13.2 (c) of the ICESCR obliges State parties to work to ensure that, 'Higher education shall be made equally accessible to all, on the basis of capacity, by every appropriate means, and in particular by the progressive introduction of free education' and that the UNESCO Convention against Discrimination in Education (1960, Article 4) also commits States to 'make higher education equally accessible to all on the basis of individual capacity', it is clear that universities should uphold the right to equal access to higher education even if this adversely affects rankings. Unfortunately, there is

\footnotetext{
$\underline{\mathbf{1 3}}$ The German CHE system does include student evaluations but this is a within-state evaluation system and does not claim to be global. CHE (Centrum für Hochschulentwicklung): www.che-ranking.de/cms/?getObject=644\&getLang $=($ accessed April 28, 2013).

${ }^{14}$ Higher education is part of the general right to education under the 1948 Universal Declaration of Human Rights (UDHR), the International Covenant on Economic, Social and Cultural Rights (ICESCR) of 1966, the Convention on the Rights of the Child (CRC) of 1989 and the UNESCO Convention against Discrimination in Education (1960) (McCowan 2012, p. 113-114).

${ }^{15}$ But not the USA.
}

evidence that this does not happen. Higher education has been the preserve of the elite in many countries and this trend is persistent over time (DuruBellat et al. 2008, Sianou-Kyrgiou 2010, McCowan 2012). Rankings are likely to exacerbate inequality of access to higher education even further (Hazelkorn 2011).

A further issue with ranking is that the determination of being 'world class' is based on criteria set by the existing academic elite: being able to acquire or retain academics with Nobel prizes or Field Medals, or to determine what constitutes elite journals, or to exclude disadvantaged students, and/or operate low staff-student ratios, are measures of worth that are only available to those that have an accumulated history of privilege, power and money. Meeting the budget target to be world class is estimated to be US\$1.5 to 2 billion per year (or $€ 1.3$ to 1.7 billion), funding that is far beyond the national budgets of many nation states (Hazelkorn 2011, p. 197).

Endowments also play a crucial role in determining ranking, effectively making it impossible for excellent universities without significant endowments to compete for a high rank. Data on the US universities shows that the larger the amount of an institution's endowment, the more likely it is to be ranked in the top 200 universities in the world (Kaba 2012, p. 26-29): Harvard's endowment in 2007 was US\$34.6 billion; Yale's was US\$22.6 billion while Stanford's was US\$17.1 billion (Kaba 2012). As the cumulative endowments of these elite universities (over US\$74 billion) are in excess of the entire tax income of many small nation states, it is evident how elite universities can retain their ranking year-on-year, while those 'below the bar' enter a cycle of disadvantage (Hazelkorn 2011, p. 93). The endowments allow elite universities to offer highly competitive salaries to attract highly cited faculty members from within the global academic market, and it enables them to give attractive scholarships to young graduates, thereby buying up the 'talent' of early stage researchers globally (Marginson \& van der Wende 2007).

As the ranking of universities is aligned with the ranking of individual academics, a new form of individualised academic capitalism is working out within higher education (Slaughter \& Leslie 2001), creating a highly competitive culture where collegiality is seriously undermined (Lynch 2010a, Ball 2012). Both individual and institutional ranking exacerbate the stratification of universities; this works to the detriment of the autonomy of universities in defining their own mission and purposes (Deem et al. 2008). 
Rankings are a type of 'consumer product ratings system', a contest in which those not listed, or listed very low down, are not in a position to establish themselves as premier institutions in any meaningful sense. When reputation is heavily weighted towards prestige, power and money, much of which is historically established, newer players cannot enter the race, or if they do, they enter and compete on terms that are not of their making and on which they cannot succeed.

\section{RANKING AND THE 'WAR FOR TALENT'}

Despite claims to the contrary, university rankings were never about meeting 'consumer' (student) needs for information in making choices in the internal education markets of higher education within nation states. Most students are allocated to universities on the basis of prior academic performance, and those who have a choice, either must have a very high performance (itself social class and racially biased) or be well enough resourced through their families to make choices (Reay et al. 2005). Even within the USA, where the US ranking scheme does influence internal choices, especially at graduate level, the choices are limited for those outside a small elite (Karabel 2005, Epseland \& Sauder 2007).

One of the core functions of university ranking, therefore, is to facilitate the international marketing of prestige programmes to elite students in highly selective and elite universities. Rankings facilitate the development of a global meritocracy at a time when 'talent' (however vaguely defined) is seen as the 'new oil' (Brown \& Tannock 2009) and 'knowledge' as the new capital. Rankings are a mechanism for ordering what has become known in popular parlance as the 'war for talent'. And stratification and selection of universities and programmes is strongly endorsed by global capitalist players such as McKinsey Consulting (Michaels et al. 2001), Microsoft and Dell (Brown \& Tannock 2009).

The discourses of the 'knowledge economy' are not just about promoting nation state economies built on highly educated workers, they are about creating banks of highly skilled workers who can and do move globally to service capital. The bonuses and salaries available to elite workers within powerful capitalist states compared to comparably skilled workers in poorer and/or smaller economies are enormous; the outcome is migration of the educated elite to the rich states. Conse- quently, poor countries experience a huge loss of highly educated workers: it is estimated that Sierra Leone has lost over $50 \%$ of its college-educated workers, while some $60 \%$ of those with higher education have emigrated from Cape Verde and Gambia and over $80 \%$ from Haiti and Jamaica over recent decades (Brown \&Tannock 2009, p. 382) $\underline{\mathbf{1 6}}$. The net beneficiaries of inward migration of highly educated workers from elite universities are powerful capitalist states that can afford to offer globally competitive salaries and working conditions (Brown \& Tannock 2009).

\section{RANKINGS AS AN IDEOLOGICAL TOOL: QUANTIFICATION, SIMPLIFICATION AND SELF-FULFILLING PROPHECIES}

In sociological terms, rankings operate as a type of politicised technological ideology that labels and stratifies a complex higher education system through simple rank ordering (Amsler \& Bolsmann 2012, p. 288). What rankings succeed in doing is providing an ostensibly 'objective' measure, a 'common cognitive space' in which the value of universities can be appraised, even if the means of achieving it is arbitrary, selective and problematic in scientific terms (Borer \& Lawn 2013, p. 49). The newspaper/online reader or television viewer is allowed to 'know' the value of a university in an instant, just by reading the rank. There is no effort involved; it is a simple accessible process. The net result is that ranks become naturalised, normalised and validated, through familiarity and ubiquitous citation, particularly through recitation as 'facts' in the media. Rankings, thus, attain an unwarranted truth status that makes them self-fulfilling by virtue of their persistence and existence. They create what they purport to measure: in-depth research on the impact of the US News and World Report Rankings on the US Law schools shows, for example, that both the status of Law schools and student choices are strongly determined by their annual ranking in USN. The rank frames the schools and the school (re)defines itself in terms of the rank (Epseland \& Sauder 2007).

\footnotetext{
${ }^{16}$ Globally, high skilled migration increased at a rate 2 and a half times faster than low skilled migration between 1990 and 2000. By 2000, the college-educated made up $34.6 \%$ of immigrants to OECD countries, up from $29.8 \%$ in 1990 , and far out of proportion to the $11.3 \%$ of the world's overall labour force that they represent (Brown \& Tannock 2009 citing Docquier \& Marfouk 2005, p. 167-168).
} 
Rankings are, in theory, an apolitical act, yet they are profoundly political. Educational outcomes and experiences have to be reduced to a numerical signifier, no matter how inappropriate that might be. Once enumerated, quality and value can only be challenged by new 'numbers' and those activities and people that cannot be enumerated cannot be included in the appraisal of quality and value (Epseland \& Sauder 2007). Whether intended or not, rankings denigrate by exclusion those activities that cannot be counted in the ordering of things.

The role of numbers in rankings is crucial to the generalised acceptance of their validity and to political disengagement from their dynamics. Numbers are unassailable to the mathematically uninitiated in a way that is not true of words; truth in numbers has a higher status, and is seen as less contestable than truth expressed in narrative form. The fear that people have of mathematics (Boaler 2008) feeds into feelings about numbers and this, in turn, feeds into the ranking industry. Fear of being 'wrong' in interpreting statistical data on rankings silences dissent from the general public, especially the media, not least because so many media personnel tend to be drawn from the non-mathematical fields, especially the humanities. They frequently lack the skills to examine the assumptions of data and numbers hidden within the ranking systems ${ }^{\frac{17}{}}$.

On the surface, the simplicity of numerical ordering appears to remove any sense of arbitrariness from the process of university rankings. It creates an impression that what is of merit can be hierarchically ordered and uncontrovertibly judged. Numbers have an aura of mystery and power and are assumed to be without ideological bias. Yet, numbers are no different to words; they come from a standpoint, a political and intellectual position and are open to interpretation (Borer \& Lawn 2013).

\section{IMPACT OF RANKING ON THE CULTURE OF THE UNIVERSITY}

There is a relatively silent colonisation of the hearts and minds of academics and students happening in universities, albeit coded in the language of accountability, progress and efficiency (Giroux 2002). The blandness and simplicity of rankings

\footnotetext{
${ }^{17}$ This observation was made by the author in an interview with the Editor of the Irish Times (Ireland's most prestigious newspaper) at a meeting in May 2013 and also by the Press Ombudsman for Ireland at a separate meeting in 2012.
}

deflects attention from the ways in which they are changing higher education, both academics and students, from the inside out (Ball 2012). Constant appraisal leads to the internalisation of an actuarial and calculative mind set both at the individual and collective levels.

As rankings form public perceptions of universities, senior administrators have to manage their ranking whether they wish to or not (Farrell \& van der Werf 2007). Thus, a range of 'gaming strategies' are deployed to advance university position in rankings (Epseland \& Sauder 2007). Rankings induce reactivity that, in turn, alters patterns of investment, intake and outputs of higher education. Universities can and do improve or retain their ranks by excluding risk factors that would downgrade their status. One of the most notable of these responses is the increased funding for 'merit' scholarships to attract elite students (Epseland \& Saunder 2007). Merit scholarships work to the advantage of the already privileged applicants for a number of reasons, mostly because educational attainment is, in the first instant, highly dependent on the expenditure of resources in a competitive system. Parents can and do use private resources to the advantage of their own children in economically unequal societies (Marsh 2011); merit scholarships merely reinforce privilege.

Ranking, auditing and measuring is also a recipe for self-display and the fabrication of image over substance among staff (Ball 2003). The heavy focus on citations as a measure of individual academic worth encourages 'gaming' or the manipulating of citation indices at the personal level (Todd \& Ladle 2008). Ranking also endorses a type of Orwellian surveillance of one's everyday work that is paralleled with a reflexive surveillance of the self. One is always measuring oneself up or down, yet there is a deep alienation in constantly living to perform (Leathwood 2005).

As trust in professional integrity and peer regulation has been replaced by performance indicators, the quality of peer relations is also diminished. Relating through audits and appraisals enhances hierarchies and diminishes goodwill and collegiality. Feelings of personal inauthenticity also emerge within a culture of compliance where one is forced to live by values and norms to which one does not subscribe (Blackmore \& Sachs 2007, Lynch et al. 2012). Rewarding staff on a measurable item-by-item performance basis also leads to a situation where personal career interests increasingly govern everyday academic life. As there are opportunities in the market for commercialised professionals and academics 
(Hanlon 2000), internal divisions between staff in the universities are inevitable and open to exploitation by management. Academic capitalism brings highly individualised rewards to those who engage (Slaughter \& Leslie 2001).

Focusing on measured performance also impacts on the cultural life of students as they are directed increasingly to economic self-interest and credential acquisition (Lolich 2011). Student and staff idealism to work in the service of humanity or in public service is seriously diminished when universities operate as entrepreneurial, purely competitive, business-oriented corporations (Elton 2000) As noted by Harkavy (2006, p. 14):

When universities openly and increasingly pursue commercialization, it powerfully legitimizes and reinforces the pursuit of economic self-interest by students and contributes to the widespread sense among them that they are in college solely to gain career skills and credentials.

The merging of commerce and research is a further consequence of marketisation. While the university has both a need and a responsibility to work with a wide range of public and private sector interests, the interests and values of business cannot drive university research, as the ethical principles and priorities of the business sector are not synonymous with those of a university (Eisenberg 1987). If universities become too reliant on industry-funded research, or too indebted to the business-driven agenda of the government of today (even if it comes coded in the guise of advancing science), there is a danger that the interests of the university become synonymous with powerful vested interests. This will undermine the purposes of the university as a research institution serving the good of humanity in its entirety and the very independence of thought that is the trademark of university research (Lieberwitz 2005). There is evidence that this is happening already in sensitive areas such as food production, genetics, biotechnology and environmental protection (Monbiot 2000). University departments are increasingly reliant on research funding from commercial operations to fund posts, especially in fields like the biosciences and engineering (Bok 2003, Washburn 2005). Given the fact that the Bayh-Dole Act (1980) in the USA allows universities and academics to benefit from patents, those academics and departments that are funded are inevitably tempted by the lure of money to compromise on ethical standards, and to defer to industry requests to control access to, or even manipulate, clinical trial data and results (Washburn 2005).
As managerial principles originated in a commercial context where process is subordinated to output and profit, managerialist values manifest themselves in education through the promotion of forms of governance (i.e. measurement, surveillance, control, regulation) that are often antithetical to the caring that is at the heart of good education. While the nurturing of learners has an outcome dimension, gains are generally not measurable in a narrowly specifiable time frame. The gains and losses from having or not having care and nurture in education are only seen over time. Moreover, the caring dimensions of education are not open to measurement in terms of quality, substance and form within a metric measurement system. Even if caring could be monitored and measured through matrices, the very doing of this would force people into the calculation of other-centeredness that would undermine the very principle of relatedness and mutuality that is at the heart of teaching and learning (Lynch 2010a).

\section{CONCLUSIONS}

Rankings have become normalised and regarded as inevitable even among those who recognise their many limitations (Hazelkorn 2011). Even powerful multilateral agencies, such as the European Commission, have accepted rankings as a given: it initiated a project in 2008 to develop a new ranking system that would be more comprehensive than those currently in use. It planned to have ranked 500 universities on multiple criteria by 2014 (www.u-multirank.eu). What is significant about the latter development is its 'methodological fetishism' (Amsler \& Bolsmann 2012, p. 292). The focus is on getting the rankings correct, even though the task of ranking incomparable institutions on multiple criteria across different countries and continents is challenging, highly risky and, arguably, of primary value to the wealthier students within a given state who can choose which university to attend (Clancy 2001, Archer et al. 2002, Karabel 2005, Epseland \& Sauder 2007).

Rankings are also problematic because their seemingly objective character conceals their serious political import. What Hacking (1990, p. 1-10) termed 'the avalanche of numbers' has 'profoundly transformed what we choose to do, who we try to be, and what we think of ourselves' in higher education. 'Assessment measures permit the easy conflation of what is with what ought to be, of what normal is in the statistical and moral sense'. The blandness of statistical measures, their perceived neutrality 'deflects 
attention from their capacity to change the places and people that use them' (Epseland \& Sauder 2007, p. 36).

One of the most serious implications of rankings is that they direct our attention into a different cognitive and normative order when evaluating higher education. Questions regarding the value, purpose and politics of higher education and rankings get swept aside in the bid to find the best 'method' of ranking. Social justice debates about access, participation and outcomes from higher education are side-lined in the 'positivist drive to make ranking technologies more and more "objective"' (Amsler \& Bolsmann 2012, p. 292).

One of the unforeseen consequences of the new cognitive spaces where ranking has led academics is the undermining of their role as public intellectuals. There is no measure for this in the rankings. Once universities and academics are ranked for only communicating with other academics (now primarily via a limited range of elite journals), and are left increasingly reliant on commercially funded research, public intellectual work is inevitably devalued. There is little incentive to invest personal time with students, to be a public intellectual and/or to investigate the vested interests behind one's own research funding. The increased elision of differences between market and public interests, and the disincentive to be either a caring teacher or public intellectual, not only privatises knowledge to closed groups, it also forecloses the opportunity to have hypotheses tested or challenged from experiential (disinterested) standpoints outside the academy. It limits the opportunities for learning that occurs when there is a dialogue between experiential and theoretical knowledge.

Rather than being bewildered and overwhelmed by the rhetoric of ranking, academics need to build a counter-hegemonic discourse to managerialism and neoliberalism in higher education, a discourse that is grounded in the principles of democracy and equality that are at the heart of the public education tradition. Academics need to reinvigorate the vision of the university as a place for universal learning and for challenging received orthodoxies (Lynch 2010b). There is an urgent need to commence a debate about the public interest values of the university (Harkavy 2006).

Acknowledgements. I thank the editor, K. Stergiou, for his exceptionally helpful comments and editorial guidance in preparing the paper for publication. I also express my appreciation to the anonymous reviewers for their feedback and direction.

\section{LITERATURE CITED}

Amsler SS, Bolsmann C (2012) University ranking as social exclusion. Br J Sociol Educ 33:283-301

Angus L (2004) Globalization and educational change; bringing about the reshaping and re-norming of practice. J Educ Policy 19:23-41

Archer L, Gilchrist R, Hutchings M, Leathwood C, Phillips D, Ross A (2002) Higher education and social class: issues of inclusion and exclusion. Falmer Press, London

Ball SJ (2003) The teacher's soul and the terrors of performativity. J Educ Policy 18:215-228

Ball SJ (2012) Performativity, commodification and commitment: An I-spy guide to the neoliberal university. Br J Educ Stud 60:17-28

Blackmore J, Sachs J (2007) Performing and reforming leaders: Gender, educational restructuring and organizational change. State of New York Press, New York, NY

Boaler J (2008) Helping children learn to love their least favorite subject-and why it's important for America. Penguin Books, New York, NY

Bok D (2003) Universities in the marketplace: the commercialization of higher education. Princeton University Press, Princeton, NJ

Boltanski L, Chiapello E (2005) The new spirit of capitalism. Verso, London

Borer V, Lawn M (2013) Governing education systems by shaping data: from the past to the present, from national to international perspectives. Eur Educ Res J 12:48-52

Brown P, Tannock S (2009) Education, meritocracy and the global war for talent. J Educ Policy 24:377-392

Bullen E, Robb S, Kenway J (2004) Creative destruction: knowledge economy policy and the future of the arts and humanities in the academy. J Educ Policy 19:3-22

Chandler J, Barry J, Clark H (2002) Stressing academe: the wear and tear of new public management. Hum Relations 55:1051-1069

Chubb J, Moe T (1990) Politics, markets and America's Schools. Brookings Institute, Washington, DC

Clancy P (1995) Access to college: patterns of continuity and change. Higher Education Authority, Dublin

Clancy P (2001) College entry in focus: a fourth national study of access to higher education. Higher Education Authority, Dublin

Clarke J, Newman J (1997) The managerial state. Sage, London

Clarke J, Gewritz S, McLaughlin E (2000) New managerialism new welfare? Sage, London

Court M (2004) Talking back to new public management versions of accountability in education. Educ Manag Administ Leadership 32:171-194

Covington S (2001) Moving a public policy agenda. Report for the National Committee for Responsive Philanthropy: Washington, DC

D'Agostino A, Serafini R, Ward-Warmedinger M (2006) Sectoral explanations of employment in Europe: the role of services. European Central Bank, Working Paper Series 625 (May 2006)

> De La Fuente JR (2002) Academic freedom and social responsibility. Higher Educ Policy 15:337-339

Deem R, Mok KH, Lucas L (2008) Transforming higher education in whose image; Exploring the concept of the 'World Class' university in Europe and Asia. Higher Educ Policy 21:83-97 
Docking J (2000) New Labour's policies for schools: raising the standard? David Fulton Publishers, London

Docquier F, Marfouk A (2005) International migration by education attainment, 1990-2000. In: Özden Ç, Schiff M (eds) International migration, remittances and the brain drain. World Bank, Washington, DC, p 151-99

Doring A (2002) Challenges to the academic role of change agent. J Further Higher Educ 26:139-148

Duru-Bellat M, Kieffer A, Reimer D (2008) Patterns of social inequalities in access to higher education in France and Germany. Int J Comp Sociol 49:347-368

ECOFIN (2010) Efficiency and effectiveness of public expenditure on tertiary education in the EU. European Commission, Brussels

Eisenberg RS (1987) Propriety rights and the norms of science. Yale Law J 97:177-231

Elton L (2000) The UK research assessment exercise: unintended consequences. Higher Educ Quart 54:274-283

Espeland WN, Sauder M (2007) Rankings and reactivity: how public measures recreate social worlds. Am J Sociol 113:1-40

Europa (2011) Council conclusions on the modernisation of higher education. Official Journal of the European Union, OJC 372/36, 20.12.2011

Farrell CM, Morris J (2003) The neo-bureaucratic state: professionals, managers and professional managers in schools, general practices and social work. Organization 10:129-156

Farrell E, van der Werf M (2007) Playing the rankings game. Chronicle of Higher Education, May 25. Available at chronicle.com/article/Playing-the-Rankings-Game/4451/ (accessed May 8, 2013)

Freire P (1970) Pedagogy of the oppressed. Penguin, London

Fukuyama F (1992) The end of history and the last man. Free Press, New York, NY

- Gamoran A (2001) American schooling and educational inequality: a forecast for the 21st century. Sociol Educ Spec Issue 74:135-153

Giroux HA (2002) Neoliberalism, corporate culture, and the promise of higher education: the university as a democratic public sphere. Harvard Educ Rev 72:1-31

Hacking I (1990) The taming of chance. Cambridge University Press, Cambridge

Hamlyn DW (1996) The concept of a university. Philosophy 71:201-218

Hanlon G (2000) Sacking the new Jerusalem? The New Right, social democracy and professional identities. Sociol Res Online 5. Available at www.socresonline.org. uk/5/1/hanlon.html (accessed August 9, 2013)

- Harkavy I (2006) The role of the universities in advancing citizenship and social justice in the 21st century. Education, Citizenship and Social Justice 1:5-37

Harvey D (2005) A brief history of neoliberalism. Oxford University Press, Oxford

Hazelkorn E (2011) Rankings and the reshaping of higher education: the battle for world class excellence. Palgrave Macmillan, Basingstoke

Henry M, Lingard B, Rizvi F, Taylor S (2001) The OECD: Globalisation and education policy. Pergamon, London

> Hill D (2005) Globalisation and its educational discontents: Neoliberalisation and its impacts on education workers' rights, pay and conditions. Int Studies Sociol Educ 15: 257-288

> Huang H (2012) Opening the black box of QS World University Rankings. Res Evaluation 21:71-78
Kaba, A J (2012) Analyzing Anglo-American hegemony in the Times Higher Education rankings. Education Policy Analysis Archives 20:1-49

Karabel J (2005) The chosen: the hidden history of admission and exclusion at Harvard, Yale and Princeton. Houghton Mifflin, Boston, MA

Knights D, Richards W (2003) Sex discrimination in UK academia. Gender, Work and Organization 10:213-238

> Leathwood C (2005) Assessment policy and practice in higher education: purpose, standards, and equity. Assess Evaluat Higher Educ 30:307-324

> Lieberwitz R (2005) Confronting the privatization and commercialization of academic research: an analysis of social implications at the local, national, and global levels. Indiana J Glob Legal Stud 12:109-152

Lo WYW (2011) Soft power, university rankings and knowledge production. Comp Educ 47(2):209-222

> Lolich L (2011) And the market created the student to its image and likening: neo-liberal governmentality and its effects on higher education. Irish Educ Stu 30:271-284

Lynch K (1995) Equality and resistance in higher education. Int Stud Sociol Educ 5:93-111

> Lynch K (2010a) Carelessness: a hidden doxa of higher education. Arts Humanities Higher Educ 9:54-67

> Lynch K (2010b) Lessons for higher education: the university as a site of activism. Br J Sociol Educ 31:575-590

Lynch K, Grummell B, Devine D (2012) New managerialism in education: Gender, commercialization and carelessness. Palgrave Macmillan, Basingstoke

Marginson S (2007a) Global university rankings: implications in general and for Australia. J Higher Educ Policy Manag 29:131-142

Marginson S (2007b) Global position and position taking: the case of Australia. J Studies Int Educ 11:5-32

> Marginson S, van der Wende M (2007) To rank or to be ranked: the impact of global rankings in higher education. J Stu Int Educ 11:306-329

Marsh J (2011) Class dismissed: Why we cannot teach or learn our way out of inequality. Monthly Review Press, New York, NY

> McCowan T (2012) Is there a universal right to higher education? Br J Educ Stud 60:111-128

Michaels E, Handfield-Jones H, Axelrod M (2001) The war for talent. Harvard Business School Press, Boston, MA

Moe MT, Bailey K, Lau R (1999) The book of knowledge: investing in the education and training industry. Merrill Lynch, New York, NY

Monbiot G (2000) The captive state. Macmillan, London

Morley L (2003) Quality and power in higher education. Society for Research into Higher Education and Open University Press, Milton Keynes

Newman JH (1852) The idea of a university: defined and illustrated. Available at www.newmanreader.org/works/ idea/ (accessed August 6, 2013)

O'Connor P (2012) Irish universities: male dominated? Equality, Diversion and Inclusion 31:83-96

OECD (Organisation for Economic Co-operation and Development) (2013) The globalisation of higher education. OECD Observer. Available at www.oecdobserver.org/ news/fullstory.php/aid/3731/The_globalisation_of_higher_ education.html (accessed April 27, 2013)

Rauhvargers A (2011) Global university rankings and their impact. European University Association, Brussels. Available at www.eua.be/pubs/Global_University_Rankings_ and_Their_Impact.pdf (accessed August 9, 2013) 
Rauhvargers A (2013) Global university rankings and their impact. Report II. European University Association, Brussels. Available at www.eua.be/Libraries/Publications_ homepage_list/EUA_Global_University_Rankings_and_ Their_Impact_-_Report_II.sflb.ashx (accessed August 1, 2013)

Reay D, David M, Ball SJ (2005) Degrees of choice: Class, race and gender in higher education. Trentham Books, London

Reay D, Crozier G, Clayton J (2010) 'Fitting in' or 'standing out': working class students in UK higher education. $\mathrm{Br}$ Educ Res J 31:1-19

Robertson SL, Bonal X, Dale R (2002) GATS and the education service industry: The politics of scale and global reterritorialization. Comp Educ Rev 46:472-496

Rumberger R W (2010) Education and the reproduction of economic inequality in the United States: An empirical investigation. Econ Educ Rev 29:246-254

Rutherford J (2005) Cultural studies in the corporate university. Cultural Stud 19:297-317

Salmi J (2009) The challenge of establishing world-class universities. The World Bank, Washington, DC

Sauder M, Epseland WN (2009) The discipline of rankings: tight coupling and organizational change. Amer Soc Rev 74:63-82

Shavit Y, Blossfeld H (1993) Persistent inequality: changing educational attainment in thirteen countries. Westview Press, Boulder, CO

Sianou-Kyrgiou E (2010) Stratification in higher education,

Editorial responsibility: Konstantinos Stergiou,

Thessaloniki, Greece choice and social inequalities in Greece. High Educ Q 64: $22-40$

Slaughter S, Leslie L (1997) Politics, policies and the entrepreneurial university. John Hopkins University Press, Baltimore, MD

Slaughter S, Leslie LL (2001) Expanding and elaborating the concept of academic capitalism. Organization 8:154-161

Sutton Trust (2007) University admissions by individual schools. Sutton Trust, London

Todd P, Ladle RJ (2008) Hidden dangers of a 'citation culture'. Ethics Sci Environ Polit 8:13-16

- Tomasevski K (2005) Globalizing what: education as a human right or as a traded service. Indiana J Glob Legal Stud 12:1-79

Tooley JN (2000) Reclaiming education. Cassell, London

Washburn J (2005) University Inc.: the corporate corruption of higher education. Basic Books, New York, NY

- Wenneras C, Wold A (1997) Nepotism and sexism in peer review. Nature 387:341-343

World Bank (1994) Higher education: the lessons of experience. The World Bank, Washington, DC

World Bank (1998) World development report: knowledge for development 1998/9. The World Bank, Oxford University Press, Washington, DC

World Bank (2002) Construction knowledge societies: new challenges for tertiary education. The World Bank, Washington, Washington, DC

World Bank (2009) The challenge of establishing world class universities. The World Bank, Washington, DC

Submitted: May 13, 2013; Accepted: August 29, 2013

Proofs received from author(s): November 8, 2013 